\title{
Artificial and Natural Membranes
}

\author{
György Váró and Zsolt Szegletes \\ Institute of Biophysics, Biological Research Centre, Szeged \\ Hungary
}

\section{Introduction}

Non-cellular forms of life are not known on the earth. Starting with unicellular organisms, such as bacteria - up to multicellular complex organisms, the basic building unit is the cell, surrounded by the cell membrane. The cell contains all the characteristics of life, having the genetic program to build up the structure and to keep it functioning.

Membranes are an essential structural component of living objects (Sybesma, 1977; Volkenstein, 1981). They are formed from different lipids and act as a selective barrier around the cell and cell organelles. The phospholipid bilayer is the basic structure of all biological membranes. Besides the phospholipids, some other lipids are generally present in the membrane, such as glycolipids and cholesterol. Many biological processes require membranes. Physically and chemically essential functions include metabolism and the process of the accumulation and usage of energy in the biological system.

An essential function of the membrane is to keep a well-defined chemical composition inside of the membrane at a limited volume, which is different from the outside. There are large concentration differences between the two sides. To build up and maintain this concentration difference, selective passive diffusion and selective active transport translocate biologically important molecules through the membrane. This is achieved by different channels and pumps built from a large variety of membrane proteins. The selectivity is achieved by the composition and structure of the transporter (Sybesma, 1977; Volkenstein, 1981).

Membrane proteins fall into two categories, depending on how they are bound to the membrane. One category is that of the peripheral proteins. They are loosely bound to the membrane through electrostatic interactions and they can be removed in lipid free-form by relatively mild treatments. In the second category are the integral proteins, embedded inside the membrane and often spanning it entirely. They are difficult to remove, having large hydrophobic domains, isolated with bound lipids. The integral membrane proteins occur in a wide variety of shapes. The most common formations are the a-helix and the $\beta$-sheet structures (Sybesma, 1977).

There are a large variety of structural possibilities and this is reflected in the very different properties and behaviour of the membrane proteins. Due to the lateral fluidity of the membrane, proteins are mobile in the surface and they can form aggregates. Large associations of proteins and lipids form rafts. By interacting with the proteins, new characteristic properties appear (Engel and Gaub, 2008). 
Over the last decade, the atomic force microscope (AFM) has become an important tool in biology. Besides of high resolution imaging single molecule experiments were performed in native environments and important parameters of the studied objects were determined, such as micro-elasticity, viscosity, dielectric property, electric charge distribution and other important parameters (Muller et al., 1997a).

\section{Sample holder surfaces}

For the modelling of a biological system, it is becoming increasingly important to understand the physical properties of living objects. In order to achieve the goal of determining their mechanical parameters, a sample is fixed to a clean surface which is flat at the atomic level. The bonds should be strong enough to avoid the dragging of the tip but equally they should not cause structural alterations to the system (Santos and Castanho, 2004).

The most commonly used support for biological samples is muscovite mica (Muller et al., 1997a). Its composition is $(\mathrm{KF})_{2}\left(\mathrm{Al}_{2} \mathrm{O}_{3}\right)_{3}\left(\mathrm{SiO}_{2}\right)_{6}\left(\mathrm{H}_{2} \mathrm{O}\right)$. Chemically it is relatively inert. The crystal structure is characterised by its layered structure. Along this layer, the cleavage yields an atomically flat surface (Figure 1, panel a). The cleaved surface has a net negative charge with an average surface charge density of $-0.0025 \mathrm{C} / \mathrm{m}^{2}$, which corresponds to 0.015 electrons per surface unit cell. By using different pre-treatments, the mica surface can fix a large variety of biological samples.
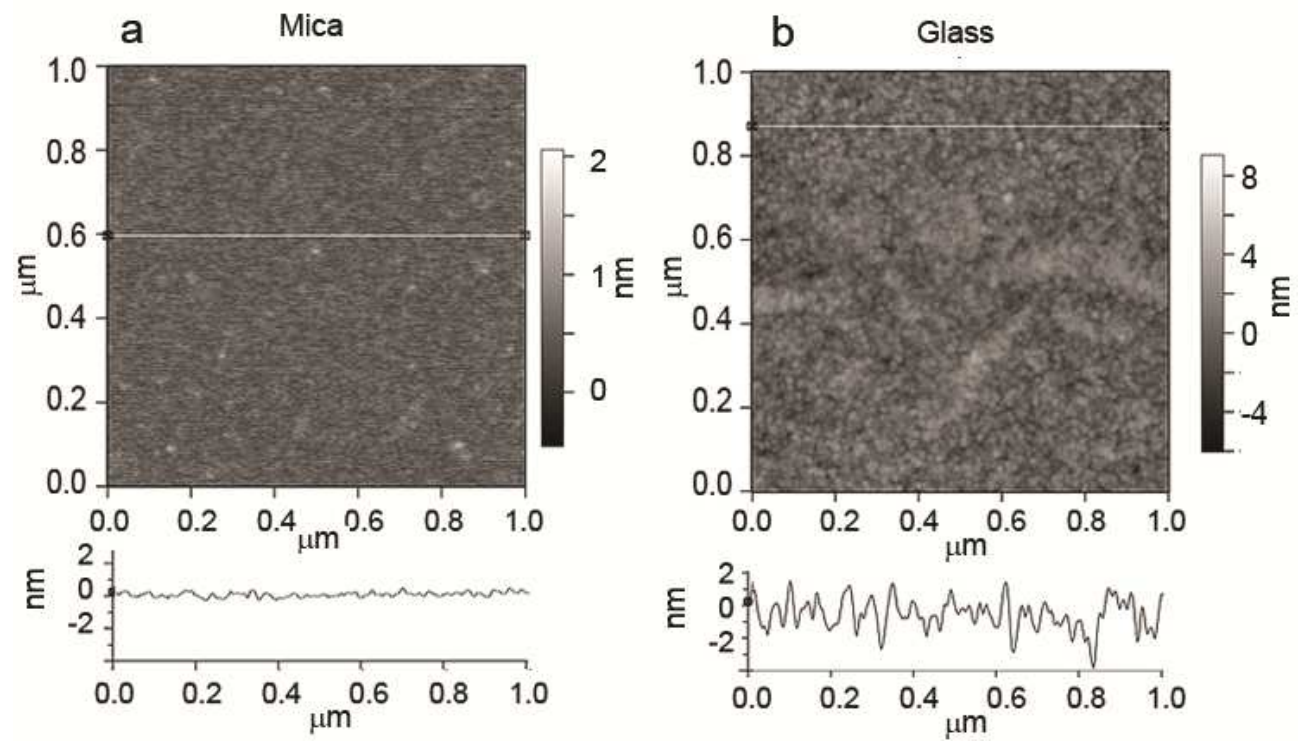

Fig. 1. High-resolution surface images of mica and glass - the materials most used by the AFM technique for membrane deposition.

Glass microscope slides or cover slips are frequently used as a transparent specimen support. The amorphous surface of the glass can be manipulated with chemical treatment, so as to fixate the biological probes (Muller et al., 1997a). Care should be taken to ensure that 
the glass surface roughness is about 1-2 nm (Figure 1, panel b), which is commensurable with the thickness of the membrane (Bálint et al., 2007a).

Highly oriented pyrolytic graphite (HOPG) is also used as a support for AFM probe if a conductive sample is prepared or a strongly hydrophobic flat surface is required for the sample preparation (Morris et al., 1999). Another possibility for manufacturing a conductive sample is by using vacuum-evaporated gold surface as the support. The gold surface binds thiols or disulphides, which can be used to covalently bind biological molecules (Muller et al., 1997a).

Nowadays, it is increasingly common to use a polished silicon wafer surface as a holder of the AFM sample. Its electrical and mechanical characteristics are well-known. Depending on the doping material used, the silicon can be positively or negatively charged (Morris et al., 1999; Bálint et al., 2007a).

The adhesion between the supporting medium and the sample strongly depends on the quality of the contact surfaces, a subject which has been intensively studied (Eastman and $\mathrm{Zhu}, 1996)$. It has been shown that the adhesive force can be accounted for by the van der Waals forces and the capillary forces between the contact surfaces (Eastman and Zhu, 1996).

\section{Artificial membranes}

Either artificial or natural membranes can be deposited on the above mentioned surfaces for AFM investigation. Artificially supported lipid membranes are model systems for the understanding of the phenomena occurring in the cell membrane. The most suitable methods for forming a supported lipid bilayer involve the Langmuir-Blodgett (LB) techniques and the fusion of lipid vesicles. LB films are formed when amphiphilic molecules interact with the air through an air-water interface. The overall effect is a reduction in the surface energy (or, equivalently, the surface tension of the water). By this method, a monolayer of lipids is compressed on an aqueous subphase. Compression/decompression isotherms are obtained by plotting the surface pressure as a function of the interfacial area. Such isotherms provide useful information about the physical state, the packing and the organisation of the lipid molecules(Dufrene et al., 1997; Rinia et al., 1999).

The LB technique allows the transferral of the monolayer of amphiphilic molecules onto a solid support - usually mica or silicon - at a constant surface pressure and a constant speed (Vie et al., 1998). If the solid support is hydrophilic - like mica - the lipid polar heads interact with the support, thus exposing the hydrophobic tails to the environment. To better mimic cellular membranes, a supported bilayer can be formed by transferring a second lipid layer onto the first mica-supported lipid monolayer. The second lipid monolayer transferred can be of different composition, thus yielding asymmetric supported lipid bilayers (Dufrene et al., 1997; Rinia et al., 1999).

The fusion of lipid vesicles on solid supports is the simplest method for preparing supported lipid bilayers (Brian and McConnell, 1984; HORN, 1984; Jass et al., 2000; Richter and Brisson, 2005). The fusion step is achieved by depositing the small unilamellar vesicle suspension onto freshly cleaved mica. Unlike LB deposition, the fusion method cannot be used to prepare asymmetric bilayers composed of two layers of a different nature. However, the fusion approach is remarkably simple, and the lateral mobility of the lipids is only 
slightly slower than in giant unilamellar vesicles (Przybylo et al., 2006), meaning that these membranes are biologically more relevant.

Multilayered polyelectrolyte films (Figure 2) prepared by the layer-by-layer consecutive adsorption method (Decher, 1997) became very popular over the past decade because of the numerous possible applications of the approach in various fields. They offer a simple and versatile tool and have surfaces with adjustable properties. These films can be functionalised with widely varying features, ranging from antifungal activity (Etienne et al., 2005) to antiinflammatory properties (Schultz et al., 2005) to electro-optical devices (Eckle and Decher, 2001). By varying the electrolytes and/or the build-up conditions, the properties of the films -such as thickness (Shiratori and Rubner, 2000), cell adhesion (Richert et al., 2002), and protein adsorption (Gergely et al., 2004) - can be largely modified (Figure 3, panels a and b).

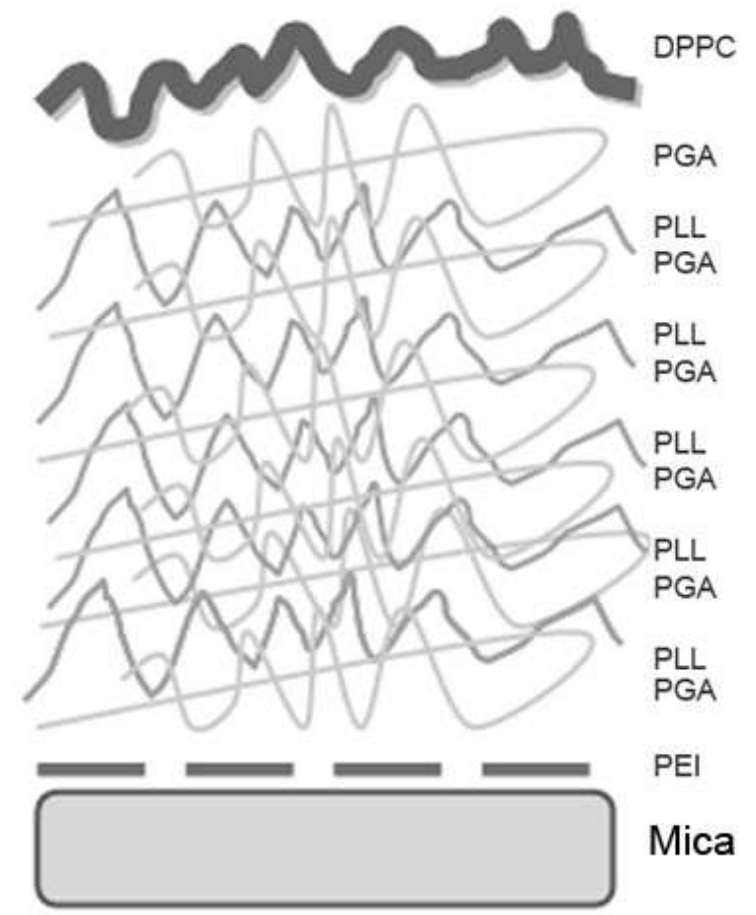

Fig. 2. Model of the structure and how the polyelectrolyte multilayer is deposited on a mica surface.

The build-up of the polyelectrolyte film began with poly(ethyleneimine) (PEI). Poly-(Lglutamic acid) (PGA)/poly(L-lysine) (PLL) polyelectrolyte film was adsorbed into the PEIcovered mica surface and then, on the surface of this film, a dipalmitoylphosphatidylcholine (DPPC) bilayer was created by the fusion of lipid vesicles. According to the AFM data, the surface roughness of the PGA/PLL film was considerably decreased by the lipid bilayer (Figure 3). In addition, the lipid surface completely closed the underlying PGA/PLL film. It seems that the forces which keep the DPPC bilayer together, in order to optimise the bilayer structure, can compress the extruding parts of the PGA/PLL films (Pilbat et al., 2007). 

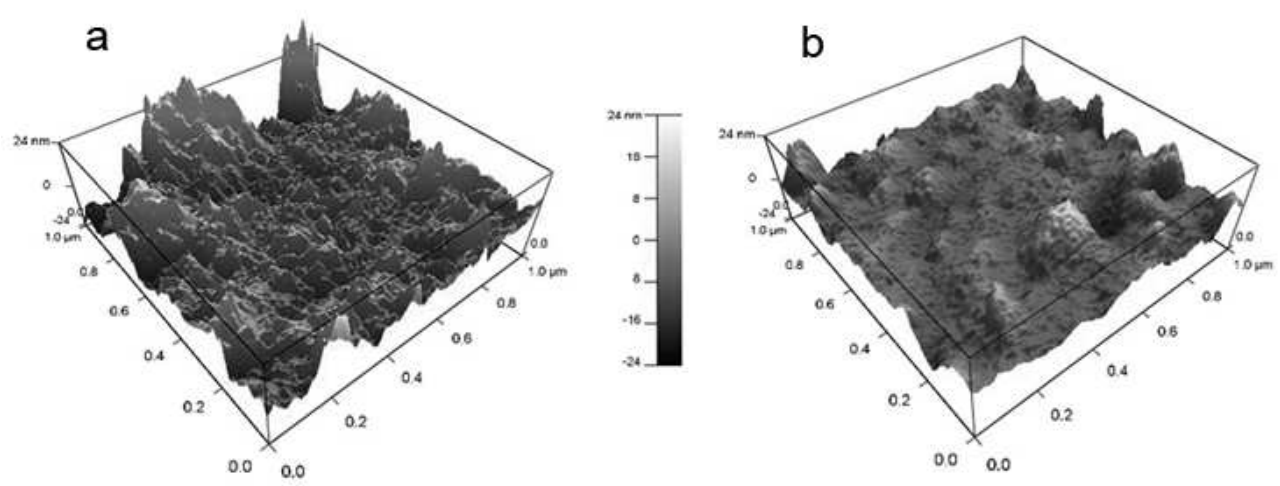

Fig. 3. High resolution image of the rough surface of polyelectrolytes (a) and its smoothed form when is covered with DPPC.

Depending on the components used, polyelectrolyte films may exhibit linear or exponential growth regimes (Lavalle et al., 2002; Gergely et al., 2004). Exponential growth requires the free diffusion of at least one of the film components in the interior of the film (Picart et al., 2002). Therefore, these films have less ordered structures than linearly growing films, which have been shown to be partially stratified with some interpenetration between neighbouring layers (Decher, 1997). Considering the extensively charged nature of the polyelectrolytes in these films, there is no chance for the direct incorporation of nonpolar, hydrophobic compounds into them. From the point of view of practical applications, however, it would be very useful if such compounds - e.g., different proteins, peptides and drugs - could be incorporated. For the incorporation of such protein molecules, lipid bilayers are needed at the very least (Figure $3 b$ ). If such bilayers were formed in the interior of polyelectrolyte films, they might be utilised as controllable internal barriers as well.

Supported lipid bilayers are readily adopted for high-resolution AFM imaging (Muller et al., 1997b; Goksu et al., 2009). A much more difficult problem is the determination of the mechanical properties of these membranes because - already at several nm indentation - the solid support is reached, thereby biasing the measured data.

\section{Membrane proteins}

Membrane proteins are involved in basic cellular functions, such as ion transport, energy or sensory stimuli transduction and information processing. Their large hydrophobic domains and their subunit structure make them able to assemble complicated structures, thus enabling them to fulfil this task. AFM provides the best tool for investigating the surface structure and mechanical properties of the membrane proteins in their native environment, which is in a physiological solution (Engel and Gaub, 2008). A great advantage of the AFM technique is that it allows individual molecules to be investigated in great detail. The high resolution imaging of the membrane provides information about the surface arrangement of the protein (Philippsen et al., 2002; Werten et al., 2002). It is possible to image the electrostatic potential of the membrane protein, such as the electrostatic potential of a transmembrane channel of the OmpF porin (Philippsen et al., 2002). 
The most studied membrane protein is the bacteriorhodopsin (BR), a light-driven proton pump. It can be found in the purple membrane of Halobacterium salinarum. The purple membrane contains only $75 \% \mathrm{w} / \mathrm{w}$ BR and $25 \%$ lipids. By separating the purple membranes by centrifugation from the cell fragments, a clean membrane protein suspension can be obtained. The separated membrane patches are strongly packed with protein into a twodimensional crystalline form (Lanyi, 2004a; Lanyi, 2004b). The BR, upon light excitation, goes through a photocycle and translocates a proton across the membrane (Oesterhelt, 1975).

A medium resolution AFM image shows the almost coin-like shape of the purple membrane patch (Figure 4). The height profile clearly shows the thickness of the membrane. On the high resolution image we can distinguish the hexagonal arrangement of the BR molecules in the membrane (Muller et al., 1995;Muller et al., 2000).
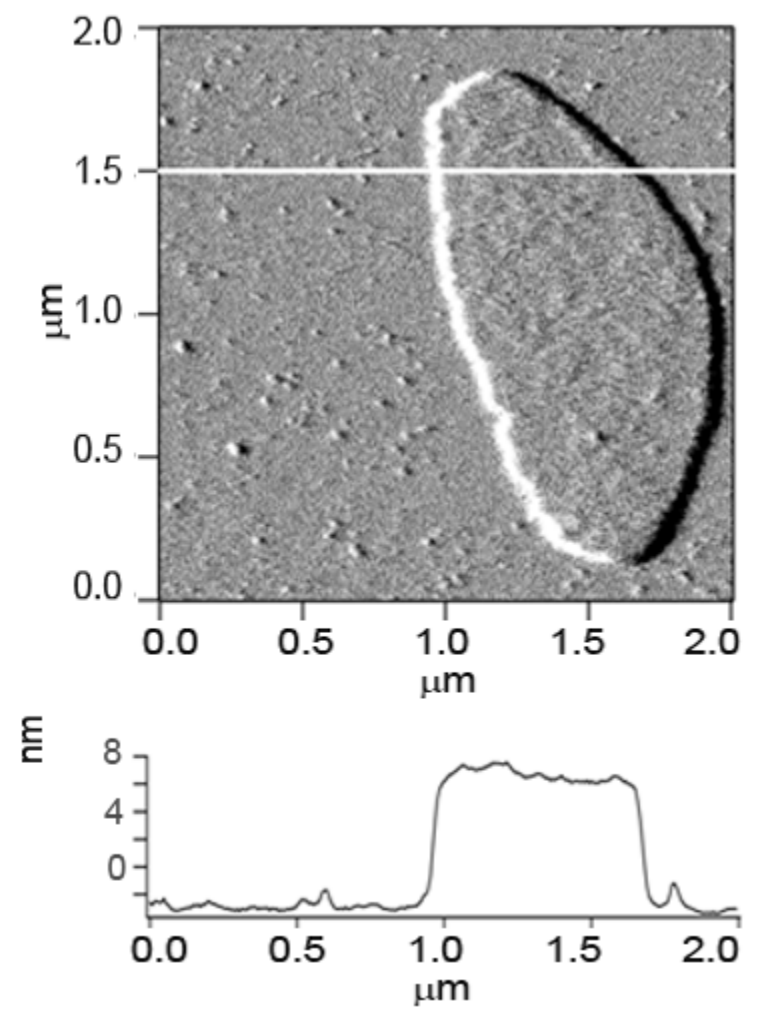

Fig. 4. The amplitude image and the height profile of a purple membrane from Halobacterium salinarum, deposited on mica. The image was taken in water.

A number of similar proteins were also imaged, such as the visual-rhodopsin (Fotiadis et al., 2003;Fotiadis et al., 2004), the chloride-pumping halorhodopsin (Persike et al., 2001) and the photosynthetic reaction centre of Rhodopseudomonas viridis (Scheuring et al., 2003;Scheuring et al., 2004). The common feature of all the imaged membrane proteins is their high density and the crystalline-like arrangement within their membranes. An image of an individual 
protein membrane is hard to obtain due to its strong interaction with the surrounding lipids (Dorogi et al., 2006).

An interesting question relates to how strong the proteins are which are bound in the membrane. To answer this, AFM experiments regarding pulling the protein were performed. The cantilever tip is chemically functionalised so as to bind to the protein. The tip is move above the membrane patch fixed to the sample compartment. By touching it to the membrane for a given time, the tip binds strongly to a protein in the membrane. By retracting the tip an increasing pulling force appears which for a moment reaches the level where a transmembrane segment of the protein is broken out. By pulling further, other membrane bounded parts of the protein can be removed. Through this, the whole binding force map of the protein is obtained (Oesterhelt et al., 2000; Janovjak et al., 2003; Janovjak et al., 2004; Ganchev et al., 2004).

\section{Effect of small peptides on supported membranes}

Antimicrobial peptides are host defence molecules produced by the innate immune system of organisms all across the evolutionary spectrum. They play a key role in the host defence system of many higher organisms (Boman, 1995). They were originally described in insects (Hultmark et al., 1980; Steiner et al., 1981) and plants (Fernandez de Caleya et al., 1972), and were subsequently identified in vertebrates (Lehrer et al., 1983; Ganz et al., 1985; Zasloff, 1987) as constituting a key component of the innate immune system. Most of the known antibacterial peptides are active against multiple microorganisms, such as viruses, bacteria, fungi and protozoa, and can be ascribed to one of three main groups: 1) a-helical peptides without cysteine, 2) peptides with three disulphide bonds, or 3) peptides rich in proline or tryptophan (Boman, 2003). AFM images of the changes on the membrane were monitored (Végh et al., 2011).

Indolicidin - encoded by a member of cathelicidin gene family and a cationic antimicrobial tridecapeptide amide - was isolated from cytoplasmic granules of bovine neutrophils (Selsted et al., 1992). It is one of the shortest known naturally-occurring antimicrobial peptides (Bowdish et al., 2005) and is toxic to both prokaryotes and eukaryotes (Falla et al., 1996; Bowdish et al., 2005). The high percentage of proline and tryptophan residues makes indolicidin a unique antimicrobial. Compared to a-helical antibiotic peptides, indolicidin is less able to dissipate the bacterial inner membrane potential and it forms smaller pores, yet it kills bacteria rapidly (Selsted et al., 1992). (Figure 5)

The purple membrane disks were deposited directly on a $\mathrm{Ca}^{2+}$ covered mica surface which is positively charged. In this case, the interaction of the purple membrane with indolicidin is quite specific. As it can be seen, indolicidin binds to the membrane. The edges were preferred (Figure 5), since the lipids are more accessible in those regions. Indolicidin attached to the membrane surface, especially on the border of membrane disk, but did not break the membrane's integrity. The surface area of the transient layer increased. This transient layer has about half the height ( $3-4 \mathrm{~nm})$ of the purple membrane. Based on the height of the layer, it is probably a monolayer of lipids stabilised with indolicidin (Végh et al., 2011).

Understanding drug-cell or drug-membrane interaction is a key issue in current biophysical and pharmaceutical research (Balashev et al., 2001; Berquand et al., 2004; Van 

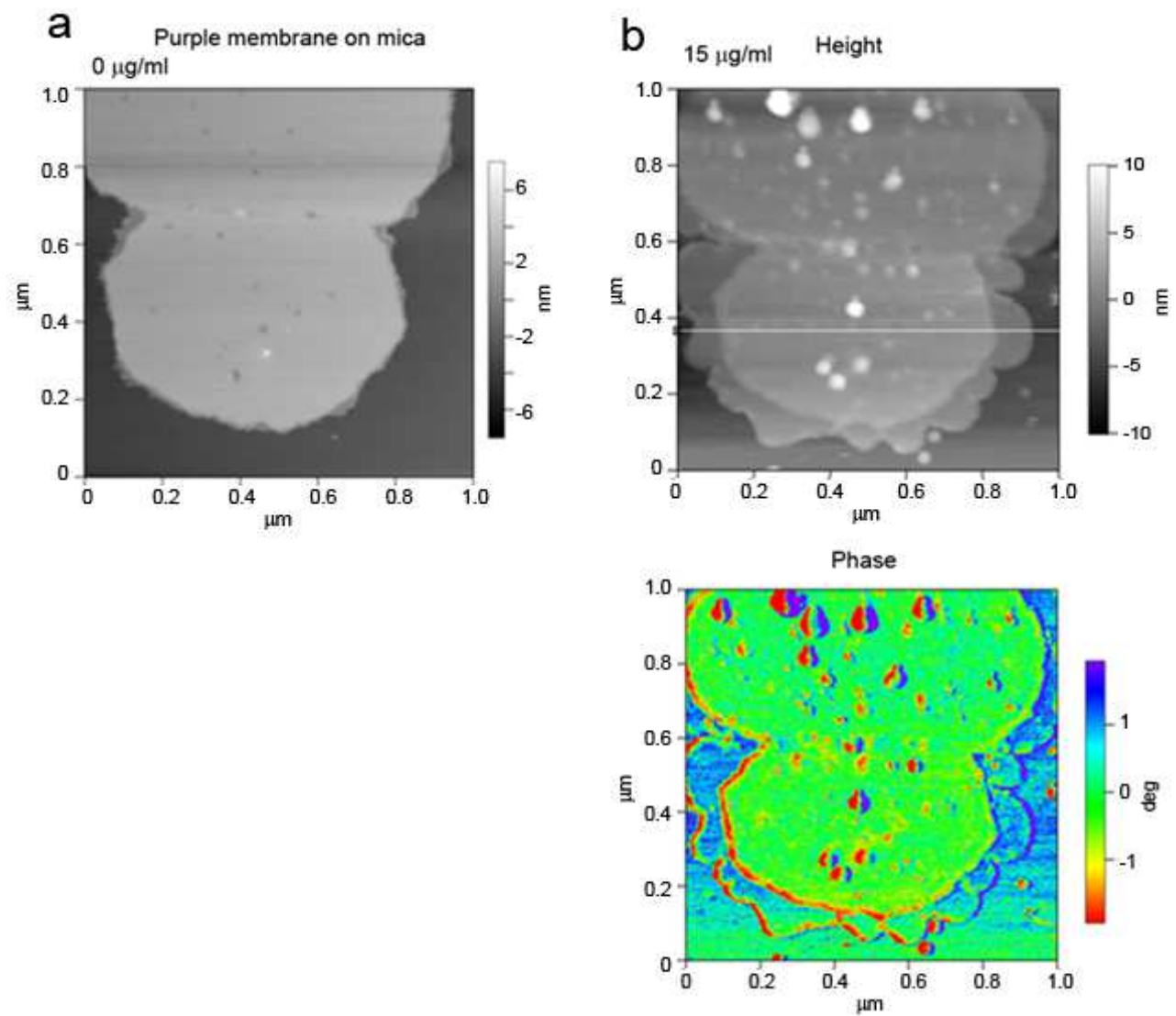

Fig. 5. The effect of the indolicidin on the purple membrane of Halobacterium salinarum (Végh et al., 2011) .

Vliet and Hinterdorfer, 2006). With AFM imaging, this interaction can be monitored in realtime at a high resolution (Berquand et al., 2004). With AFM it was possible to show the change of the cell elasticity when the membrane was cross-linked with an anti-cytoskeletal drug (Wu et al., 1998).

Lipid rafts are formed when large numbers of membrane proteins are interacting and aggregate on a closed configuration. The proteins inside the lipid raft can get new properties by interacting with others. An example of this are the bacteriorhodopsin in the purple membrane which interact with each other, regulating the photocycle (Tokaji, 1995; Dancsházy and Tokaji, 2000). As a matter of fact, the purple membrane packed with bacteriorhodopsin is a raft. There is a transition in the lipid composition and membrane protein density at the border of the raft, which can be detected by AFM (Poole et al., 2004; Johnston, 2009). 
The membranes which are tightly-packed with protein give a good opportunity to observe the conformational change of the protein during its function (Lewis et al., 1996; Persike et al., 2000). Where there is a protein in the crystal lattice with a changed conformation, the surface symmetry is altered. Such an event was observed by the bleaching of the BR (Stahlberg et al., 2001; Braun et al., 2006). A drawback of the method is that the fast reversible processes of the conformational changes cannot be observed (Braun et al., 2006).

The instantaneous, fast conformational change of the bacteriorhodopsin was registered by an unusual arrangement of the AFM (Figure 6). The purple membranes were electrophoretically deposited in oriented-mode on a conducting cantilever (Figure 6, panel a). When the BR is excited by light, the protein goes through a photocycle, during which a conformational change occurs. The protein produces a volume change during the conformational motion which results in a deflection of the cantilever (Figure 6, panel b) (Bálint et al., 2007b).
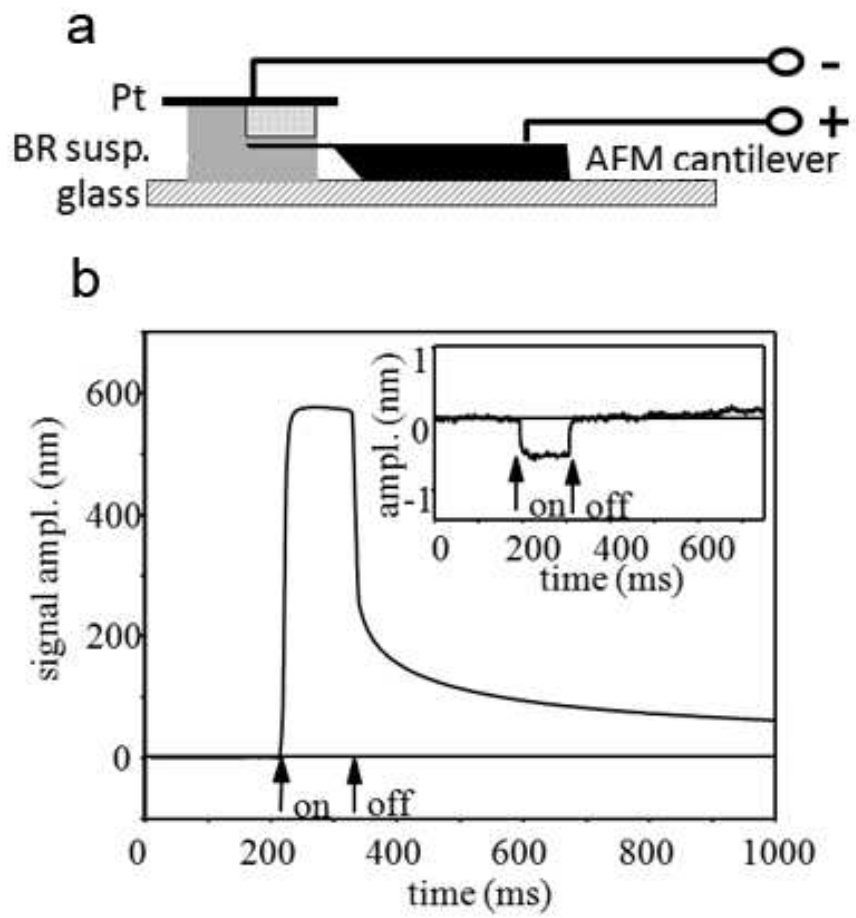

Fig. 6. The electrophoretic deposition of the purple membrane (a) and the deflection signal measured during illumination of the cantilever $(b)$. The inset is a control signal measured with an empty cantilever (Bálint et al., 2007b) .

Several biological application of the AFM was presented. The study focused on a functionally important part of the living material, the lipid membrane. It was discussed how the membranes are deposited on a solid support for sampling and what kind of changes were observed during the measurements. 


\section{Acknowledgment}

This work was supported by the National Science Fund of Hungary OTKA K81180 and by the COST Action TD1002.

\section{References}

Balashev K., Jensen T.R., Kjaer K., and Bjornholm T. (2001). Novel methods for studying lipids and lipases and their mutual interaction at interfaces. Part I. Atomic force microscopy. Biochimie 83:387-397.

Bálint Z., Nagy K., Laczkó I., Bottka S., Végh G.A., Szegletes Z., and Váró G. (2007a). Adsorption and self-assembly of oligodeoxynucleotides onto a mica surface. J. Phys. Chem. C 111:17032-17037.

Bálint Z., Végh G.A., Popescu A., Dima M., Ganea C., and Váró G. (2007b). Direct observation of protein motion during the photochemical reactio cycle of bacteriorhodopsin. Langmuir 23:7225-7228.

Berquand A., Mingeot-Leclercq M.P., and Dufrene Y.F. (2004). Real-time imaging of drugmembrane interactions by atomic force microscopy. Biochimica et Biophysica ActaBiomembranes 1664:198-205.

Boman H.G. (1995). Peptide antibiotics and their role in innate immunity. Annu. Rev. Immunol. 13:61-92.

Boman H.G. (2003). Antibacterial peptides: basic facts and emerging concepts. J. Intern. Med. 254:197-215.

Bowdish D.M., Davidson D.J., Scott M.G., and Hancock R.E. (2005). Immunomodulatory activities of small host defense peptides. Antimicrob. Agents Chemother. 49: 1727-1732.

Braun T., Backmann N., Vogtli M., Bietsch A., Engel A., Lang H.P., Gerber C., and Hegner M. (2006). Conformational change of bacteriorhodopsin quantitatively monitored by microcantilever sensors. Biophys. J. 90:2970-2977.

Brian A.A. and McConnell H.M. (1984). Allogeneic stimulation of cytotoxic T cells by supported planar membranes. Proc. Natl. Acad. Sci. U. S. A. 81:6159-6163.

Dancsházy Z. and Tokaji Z. (2000). Blue light regeneration of bacteriorhodopsin bleached by continuous light. FEBS Lett. 476:171-173.

Decher G. (1997). Fuzzy nanoassemblies: Toward layered polymeric multicomposites RID E7665-2011. Science 277:1232-1237.

Dorogi M., Bálint Z., Mikó C., Vileno B., Milas M., Hernadi K., Forro L., Váró G., and Nagy L. (2006). Stabilization effect of single-walled carbon nanotubes on the functioning of photosynthetic reaction centers. J. Phys. Chem. B 110:21473-21479.

Dufrene Y.F., Barger W.R., Green J.B.D., and Lee G.U. (1997). Nanometer-scale surface properties of mixed phospholipid monolayers and bilayers. Langmuir 13: 4779-4784.

Eastman T. and Zhu D.M. (1996). Adhesion forces between surface-modified AFM tips and a mica surface. Langmuir 12:2859-2862.

Eckle M. and Decher G. (2001). Tuning the performance of layer-by-layer assembled organic light emitting diodes by controlling the position of isolating clay barrier sheets RID E-7665-2011. Nano Letters 1:45-49. 
Engel A. and Gaub H.E. (2008). Structure and mechanics of membrane proteins. Annual Review Of Biochemistry 77:127-148.

Etienne O., Gasnier C., Taddei C., Voegel J.C., Aunis D., Schaaf P., Metz-Boutigue M.H., Bolcato-Bellemin A.L., and Egles C. (2005). Antifungal coating by biofunctionalized polyelectrolyte multilayered films. Biomaterials 26:6704-6712.

Falla T.J., Karunaratne D.N., and Hancock R.E. (1996). Mode of action of the antimicrobial peptide indolicidin. J. Biol. Chem. 271:19298-19303.

Fernandez de Caleya R., Gonzalez-Pascual B., Garcia-Olmedo F., and Carbonero P. (1972). Susceptibility of phytopathogenic bacteria to wheat purothionins in vitro. Appl. Microbiol. 23:998-1000.

Fotiadis D., Liang Y., Filipek S., Saperstein D.A., Engel H.A., and Palczewski K. (2003). Atomic-force microscopy: Rhodopsin dimers in native disc membranes. Nature 421:127-128.

Fotiadis D., Liang Y., Filipek S., Saperstein D.A., Engel H.A., and Palczewski K. (2004). The $\mathrm{G}$ protein-coupled receptor rhodopsin in the native membrane. Febs Letters 564:281-288.

Ganchev D.N., Rijkers D.T.S., Snel M.M.E., Killian J.A., and Kruijff B. (2004). Strength of integration of transmembrane a-helical peptides in lipiid bilayers as determined by atomic force spectroscopy. Biochemistry 43:14987-14993.

Ganz T., Selsted M.E., Szklarek D., Harwig S.S., Daher K., Bainton D.F., and Lehrer R.I. (1985). Defensins. Natural peptide antibiotics of human neutrophils. J. Clin. Invest. 76:1427-1435.

Gergely C., Bahi S., Szalontai B., Flores P., Schaaf P., Voegel J.C., and Cuisinier F.J.G. (2004). Human serum albumin self-assembly on weak polyelectrolyte multilayer films structurally modified by $\mathrm{pH}$ changes. Langmuir 20:5575-5582.

Goksu E.I., Vanegas J.M., Blanchette C.D., Lin W.C., and Longo M.L. (2009). AFM for structure and dynamics of biomembranes. Biochim. Biophys. Acta 1788:254-266.

Horn R.G. (1984). Direct Measurement of the Force between 2 Lipid Bilayers and Observation of their Fusion. Biochim. Biophys. Acta 778:224-228.

Hultmark D., Steiner H., Rasmuson T., and Boman H.G. (1980). Insect immunity. Purification and properties of three inducible bactericidal proteins from hemolymph of immunized pupae of Hyalophora cecropia. Eur. J. Biochem. 106:7-16.

Janovjak H., Kessler M., Oesterhelt D., Gaub H.E., and Muller D.J. (2003). Unfolding pathways of native bacteriorhodopsin depend on temperature. Embo Journal 22:5220-5229.

Janovjak H., Struckmeier J., Hubain M., Kedrov A., Kessler M., and Muller D.J. (2004). Probing the energy landscape of the membrane protein bacteriorhodopsin. Structure 12:871-879.

Jass J., Tjarnhage T., and Puu G. (2000). From liposomes to supported, planar bilayer structures on hydrophilic and hydrophobic surfaces: an atomic force microscopy study. Biophys. J. 79:3153-3163.

Johnston L.J. (2009). Nanoscale imaging of domains in supported lipid membranes. Langmuir 23:5886-5895.

Lanyi J.K. (2004a). Bacteriorhodopsin. Annual Review of Physiology 66:665-688. 
Lanyi J.K. (2004b). Transport mechanism in bacteriorhodopsin. Abstracts Of Papers Of The American Chemical Society 225:U521.

Lavalle P., Gergely C., Cuisinier F.J.G., Decher G., Schaaf P., Voegel J.C., and Picart C. (2002). Comparison of the structure of polyelectrolyte multilayer films exhibiting a linear and an exponential growth regime: An in situ atomic force microscopy study RID E-7665-2011. Macromolecules 35:4458-4465.

Lehrer R.I., Selsted M.E., Szklarek D., and Fleischmann J. (1983). Antibacterial activity of microbicidal cationic proteins 1 and 2, natural peptide antibiotics of rabbit lung macrophages. Infect. Immun. 42:10-14.

Lewis A., Rousso I., Khachatryan E., Brodsky I., Lieberman K., and Sheves M. (1996). Directly probing rapid membrane protein dynamics with an atomic force microscope: A study of light-induced conformational alterations in bacteriorhodopsin. Biophys. J. 70:2380-2384.

Morris V.J., Kirby A.R., and Gunning A.P. 1999. Atomic force microscopy for biologists. London, UK.

Muller D.J., Engel H.A., and Amrein M. (1997a). Preparation techniques for the observation of native biological systems with the atomic force microscope. Biosensors \& Bioelectronics 12:867-877.

Muller D.J., Heymann J.B., Oesterhelt F., Moller C., Gaub H.E., Buldt G., and Engel H.A. (2000). Atomic force microscopy of native purple membrane. Biochimica Et Biophysica Acta-Bioenergetics 1460:27-38.

Muller D.J., Schabert F.A., Buldt G., and Engel H.A. (1995). ImagingPurple membrane in aqueous-solutions at subnanometer resolution by atomic-force microscopy. Biophys. J. 68:1681-1686.

Muller D.J., Schoenenberger C.A., Schabert F.A., and Engel H.A. (1997b). Structural changes in native membrane proteins monitored at subnanometer resolution with the atomic force microscope: A review. Journal Of Structural Biology 119:149-157.

Oesterhelt D. (1975). The purple membrane of Halobacterium halobium: a new system for light energy conversion. Ciba. Found. Symp.147-167.

Oesterhelt F., Oesterhelt D., Pfeiffer M., Engel H.A., Gaub H.E., and Muller D.J. (2000). Unfolding pathways of individual bacteriorhodopsins. Science 288:143-146.

Persike N., Pfeiffer M., Guckenberger R., and Fritz M. (2000). Changes in the surface structure of purple membrane upon illumination measured by atomic force microscopy. Colloids And Surfaces B-Biointerfaces 19:325-332.

Persike N., Pfeiffer M., Guckenberger R., Radmacher M., and Fritz M. (2001). Direct observation of different surface structures on high- resolution images of native halorhodopsin. Journal Of Molecular Biology 310:773-780.

Philippsen A., Im W.P., Engel H.A., Schirmer T., Roux B., and Muller D.J. (2002). Imaging the electrostatic potential of transmembrane channels: Atomic probe microscopy of OmpF porin. Biophys. J. 82:1667-1676.

Picart C., Mutterer J., Richert L., Luo Y., Prestwich G.D., Schaaf P., Voegel J.C., and Lavalle P. (2002). Molecular basis for the explanation of the exponential growth of polyelectrolyte multilayers. Proc. Natl. Acad. Sci. U. S. A. 99:12531-12535.

Pilbat A.M., Szegletes Z., Kóta Z., Ball V., Schaaf P., Voegel J.C., and Szalontai B. (2007). Phospholipid bilayers as biomembrane-like barriers in layer-by-layer polielectrolyte films. Langmuir 23:8236-8242. 
Poole K., Meder D., Simons K., and Muller D. (2004). The effect of raft lipid depletion on microvilli formation in MDCK cells, visualized by atomic force microscopy. Febs Letters 565:53-58.

Przybylo M., Sykora J., Humpolickova J., Benda A., Zan A., and Hof M. (2006). Lipid diffusion in giant unilamellar vesicles is more than 2 times faster than in supported phospholipid bilayers under identical conditions. Langmuir : the ACS journal of surfaces and colloids 22:9096-9099.

Richert L., Lavalle P., Vautier D., Senger B., Stoltz J.F., Schaaf P., Voegel J.C., and Picart C. (2002). Cell interactions with polyelectrolyte multilayer films. Biomacromolecules 3:1170-1178.

Richter R.P. and Brisson A.R. (2005). Following the formation of supported lipid bilayers on mica: a study combining AFM, QCM-D, and ellipsometry. Biophys. J. 88:3422-3433.

Rinia H.A., Demel R.A., van der Eerden J.P., and de Kruijff B. (1999). Blistering of langmuirblodgett bilayers containing anionic phospholipids as observed by atomic force microscopy. Biophys. J. 77:1683-1693.

Santos N.C. and Castanho M.A.R.B. (2004). An overview of the biophysical applications of atomic force microscopy. Biophysical Chemistry 107:133-149.

Scheuring S., Seguin J., Marco S., Levy D., Robert B., and Rigaud J. (2003). Nanodissection and high-resolution imaging of the Rhodopseudomonas viridis photosynthetic core complex in native membranes by AFM. Proc. Natl. Acad. Sci. U. S. A. 100: 1690-1693.

Scheuring S., Sturgis J.N., Prima V., Bernadac A., Levy D., and Rigaud J.L. (2004). Watching the photosynthetic apparatus in native membranes. Proc. Natl. Acad. Sci. U. S. A. 101:11293-11297.

Schultz P., Vautier D., Richert L., Jessel N., Haikel Y., Schaaf P., Voegel J.C., Ogier J., and Debry C. (2005). Polyelectrolyte multilayers functionalized by a synthetic analogue of an anti-inflammatory peptide, alpha-MSH, for coating a tracheal prosthesis. Biomaterials 26:2621-2630.

Selsted M.E., Novotny M.J., Morris W.L., Tang Y.Q., Smith W., and Cullor J.S. (1992). Indolicidin, a novel bactericidal tridecapeptide amide from neutrophils. J. Biol. Chem. 267:4292-4295.

Shiratori S.S. and Rubner M.F. (2000). pH-dependent thickness behavior of sequentially adsorbed layers of weak polyelectrolytes. Macromolecules 33:4213-4219.

Stahlberg H., Fotiadis D., Scheuring S., Remigy H., Braun T., Mitsuoka K., Fujiyoshi Y., and Engel H.A. (2001). Two-dimensional crystals: a powerful approach to assess structure, function and dynamics of membrane proteins. Febs Letters 504:166-172.

Steiner H., Hultmark D., Engstrom A., Bennich H., and Boman H.G. (1981). Sequence and specificity of two antibacterial proteins involved in insect immunity. Nature 292:246-248.

Sybesma,C. 1977. Membranes. In Biophysics An Introduction. Kluwer Academic Publisher, Dordrecht/Boston/London. 29-36.

Tokaji Z. (1995). Cooperativity-regulated parallel pathways of the bacteriorhodopsin photocycle. FEBS Lett. 357:156-160.

Van Vliet K.J. and Hinterdorfer P. (2006). Probing drug-cell interactions. Nanotoday 1:18-25. 
Végh G.A., Nagy K., Bálin Z., Kerényi Á., Rákhely G., Váró G., and Szegletes Z. (2011). Effect of antimicrobial peptide-amide,indolicidin on biological membranes. J. Biomed. Biotechnol. doi:10.1155./2011/670589

Vie V., Van Mau N., Lesniewska E., Goudonnet J.P., Heitz F., and Le Grimellec C. (1998). Distribution of ganglioside G(M1) between two-component, two-phase phosphatidylcholine monolayers. Langmuir 14:4574-4583.

Volkenstein,M. 1981. Physique des membanes. In Biophysique. Moscou. 345-75.

Werten P.J.L., Remigy H.W., de Groot B.L., Fotiadis D., Philippsen A., Stahlberg H., Grubmuller H., and Engel H.A. (2002). Progress in the analysis of membrane protein structure and function. Febs Letters 529:65-72.

Wu H.W., Kuhn T., and Moy V.T. (1998). Mechanical properties of 1929 cells measured by atomic force microscopy: Effects of anticytoskeletal drugs and membrane crosslinking. Scanning 20:389-397.

Zasloff M. (1987). Magainins, a class of antimicrobial peptides from Xenopus skin: isolation, characterization of two active forms, and partial cDNA sequence of a precursor. Proc. Natl. Acad. Sci. U. S. A. 84:5449-5453. 


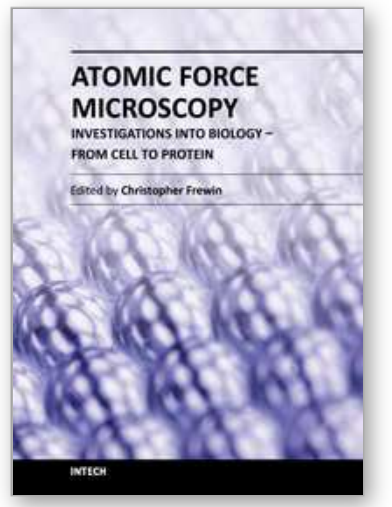

\author{
Atomic Force Microscopy Investigations into Biology - From Cell \\ to Protein \\ Edited by Dr. Christopher Frewin
}

ISBN 978-953-51-0114-7

Hard cover, 354 pages

Publisher InTech

Published online 07, March, 2012

Published in print edition March, 2012

The atomic force microscope (AFM) has become one of the leading nanoscale measurement techniques for materials science since its creation in the 1980 's, but has been gaining popularity in a seemingly unrelated field of science: biology. The AFM naturally lends itself to investigating the topological surfaces of biological objects, from whole cells to protein particulates, and can also be used to determine physical properties such as Young's modulus, stiffness, molecular bond strength, surface friction, and many more. One of the most important reasons for the rise of biological AFM is that you can measure materials within a physiologically relevant environment (i.e. liquids). This book is a collection of works beginning with an introduction to the AFM along with techniques and methods of sample preparation. Then the book displays current research covering subjects ranging from nano-particulates, proteins, DNA, viruses, cellular structures, and the characterization of living cells.

\title{
How to reference
}

In order to correctly reference this scholarly work, feel free to copy and paste the following:

György Váró and Zsolt Szegletes (2012). Artificial and Natural Membranes, Atomic Force Microscopy Investigations into Biology - From Cell to Protein, Dr. Christopher Frewin (Ed.), ISBN: 978-953-51-0114-7, InTech, Available from: http://www.intechopen.com/books/atomic-force-microscopy-investigations-into-biologyfrom-cell-to-protein/artificial-and-natural-membranes

\section{INTECH}

open science | open minds

\author{
InTech Europe \\ University Campus STeP Ri \\ Slavka Krautzeka 83/A \\ 51000 Rijeka, Croatia \\ Phone: +385 (51) 770447 \\ Fax: +385 (51) 686166 \\ www.intechopen.com
}

\author{
InTech China \\ Unit 405, Office Block, Hotel Equatorial Shanghai \\ No.65, Yan An Road (West), Shanghai, 200040, China \\ 中国上海市延安西路65号上海国际贵都大饭店办公楼 405 单元 \\ Phone: +86-21-62489820 \\ Fax: +86-21-62489821
}


(C) 2012 The Author(s). Licensee IntechOpen. This is an open access article distributed under the terms of the Creative Commons Attribution 3.0 License, which permits unrestricted use, distribution, and reproduction in any medium, provided the original work is properly cited. 